\title{
Identification of groundwater chemistry origins in a regional aquifer system (Wielkopolska region, Poland)
}

\author{
K. Dragon · J. Gorski
}

Received: 8 August 2013/ Accepted: 29 July 2014/Published online: 10 August 2014

(C) The Author(s) 2014. This article is published with open access at Springerlink.com

\begin{abstract}
This paper describes the origin of the groundwater chemistry in the regional aquifer located in the Wielkopolska region of western Poland. Factor analysis was used for the identification of geochemical processes that influence the groundwater chemistry. Two groups of processes were identified: anthropogenic (i.e., caused by groundwater contamination) and geogenic (i.e., caused by natural geochemical processes). Based on a background of the natural variations in the groundwater chemistry, the effect of upward groundwater flow from the deep part of the flow system on the groundwater chemistry was identified. The boron concentrations and isotope data allowed for the identification of zones of relatively old groundwater. The spatial distribution of fluoride concentrations allowed for the identification of recharge zones. This study demonstrates the general usefulness of groundwater chemistry differentiation for supporting identification of groundwater flow patterns. It also demonstrates the importance of using chemical data to evaluate the connectivity between different aquifers. These interpretations can be used for better management of water resources on a regional scale.
\end{abstract}

Keywords Factor analyses - Groundwater chemistry · Hydrochemical zoning $\cdot$ Poland $\cdot$ Regional aquifer system

K. Dragon $(\bowtie) \cdot J$. Gorski

Department of Hydrogeology and Water Protection, Institute of Geology, Adam Mickiewicz University Poznan, Makow Polnych Street 16, 61-606 Poznan, Poland

e-mail: smok@amu.edu.pl

\section{Introduction}

Determining the origin of groundwater chemistry is crucial for effective water resource management and protection (Jeong 2001; Moosavirad et al. 2013; Perea and Rodriguez-Rodriguez 2009; Tweed et al. 2005). Many studies have shown that changes in groundwater chemistry can help in determining the flow pattern occurring in the aquifers (Afsin 1996; Coetsiers and Walraevens 2006; Hendry and Schwartz 1990; Jackson and Lloyd 1984; Ophori and Toth 1989; Ochsenkuhn et al. 1997). This information is particularly important in groundwater systems where the hydrogeology is complex due to the presence of multiple aquifers. In the case of multilayer aquifer systems, the spatial variations in groundwater chemistry can help in determining the vertical interactions of the groundwater between different aquifers (AlMashaikhi et al. 2012; Carillo-Rivera et al. 1996; Pilla et al. 2006).

The use of major ions as natural tracers is a common method for identifying flow paths in aquifers (Back 1966). The general approach is to assign water samples to groups (called hydrochemical facies or hydrochemical zones) with similar hydrochemical characteristics, which can then be correlated with locations (Thyne et al. 2004). These facies are a function of chemical processes operating within the lithologic framework and within the flow patterns of the water (Back 1966). The differences between the chemical facies of these groups can provide insight into the aquifer connectivity and the chemical processes controlling the groundwater chemistry.

In the present study, multi-component geochemical tracers in conjunction with physical parameters were used for investigating the flow conditions. Certain trace elements (i.e., boron and fluoride) were used to qualitatively 


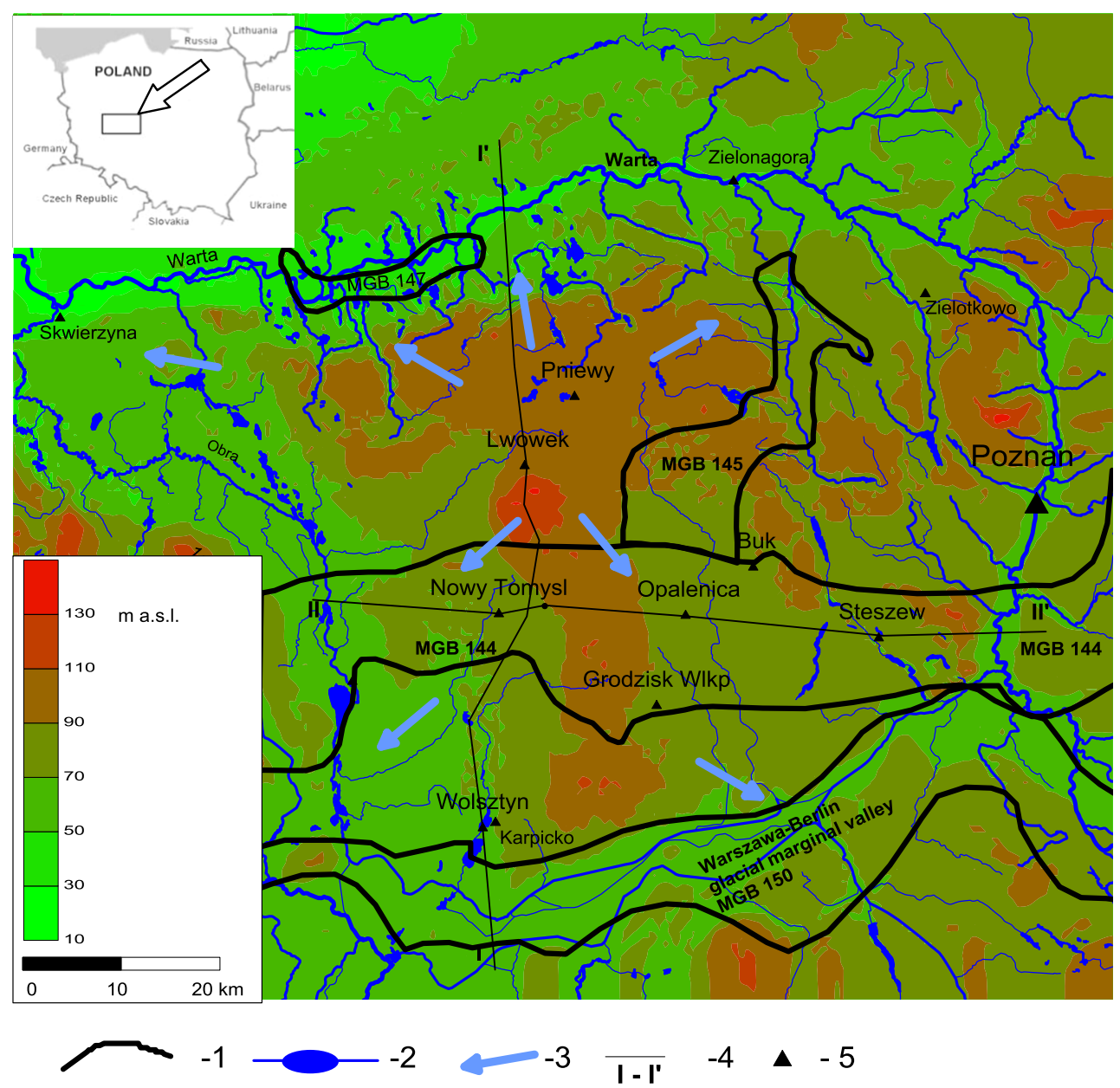

Fig. 1 The location of the study area on a background of the land relief (after Dragon 2013, modified), 1 the boundaries of the major groundwater basins; 2 surface water (lakes and rivers); 3 general groundwater flow directions; 4 the lines of cross-sections: $A$ crosssection I-I', $B$ cross-section II-II' (Fig. 2); 5 main towns

study focused primarily on the natural groundwater processes affecting the groundwater chemistry.

\section{The study area}

The study area is located in the western part of the Wielkopolska region, which is in the western Polish Lowlands (Fig. 1). The central part of this region is at an elevation of $138 \mathrm{~m}$ a.s.l. (above sea level). From this central location, the ground slopes downward in all directions to $\sim 60 \mathrm{~m}$ a.s.l. in the Obra Valley (to the west), Warta Valley (to the east) and Warszawa-Berlin glacial marginal valley (to the south) and to $<20 \mathrm{~m}$ a.s.l. in the Warta Valley (to the north) (Fig. 1).

The Quaternary sediments are more than $130 \mathrm{~m}$ thick in the central part of the region, thinning to $\sim 60 \mathrm{~m}$ in the Warszawa-Berlin glacial margin valley area and to $<40 \mathrm{~m}$ in the Warta Valley (northern part of the study area) 

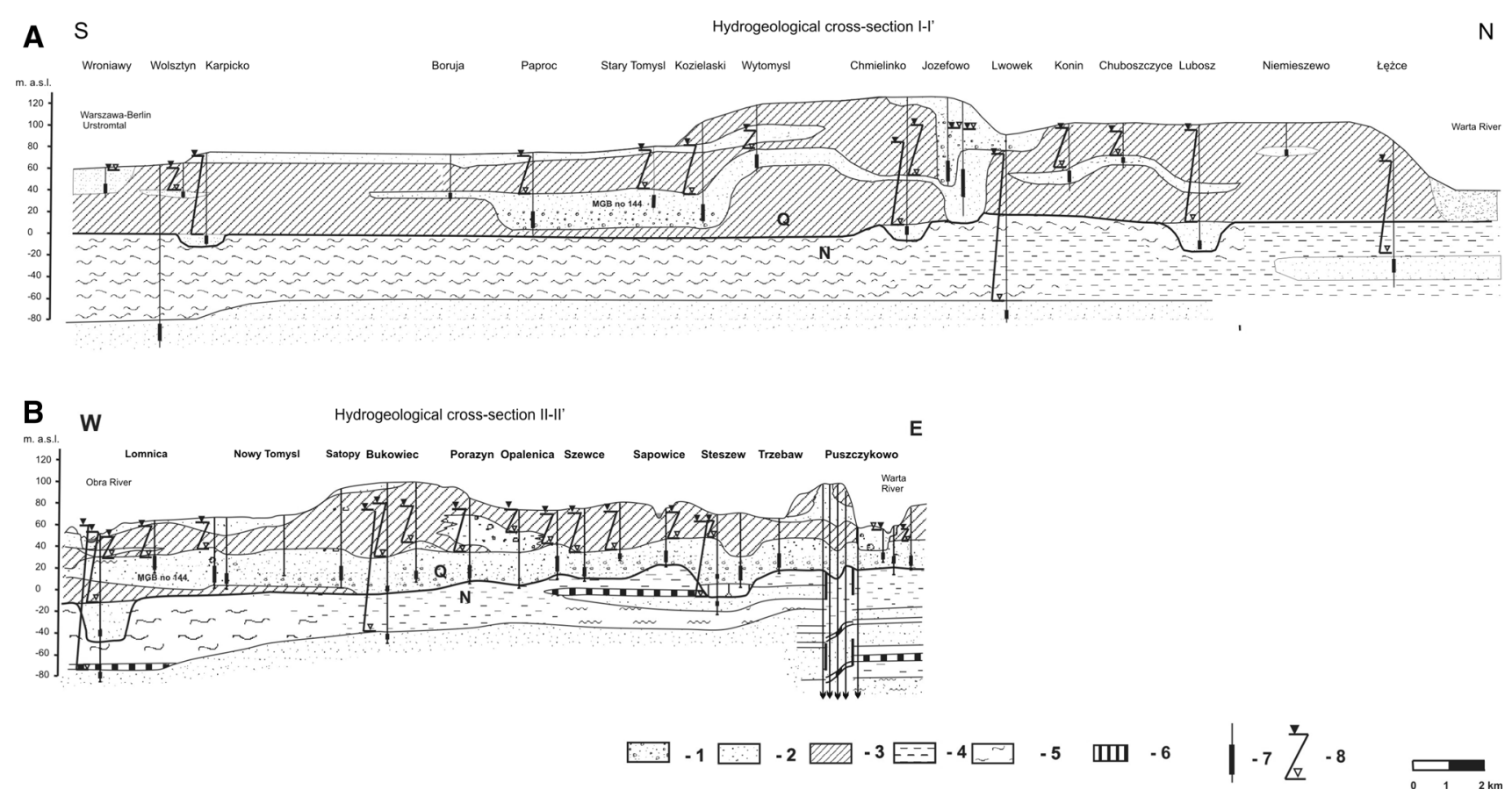

Fig. 2 The hydrogeological cross-Sects. 1 coarse sand and gravel, 2 medium and fine sand, 3 till, 4 clay, 5 silt, 6 brown coal, 7 the location of the well screen, 8 ground water level, $Q$ quaternary, $N$ neogene

(Fig. 2). The lithology is dominated by glacial and fluvioglacial deposits. The fluvioglacial sands and gravels comprise the aquifers, which consist of a multilayer system in certain areas. The deepest aquifers are $\sim 20-30 \mathrm{~m}$ thick and are primarily composed of fine sands. These deep aquifers were discovered only locally in the part of the region where there are no shallow aquifers. The shallow aquifers are connected to the Wielkopolska buried valley (WBV) aquifer system, which is located in the central part of the study area. These aquifers vary from 30 to $40 \mathrm{~m}$ thick. The lithology is dominated by fine and medium sands of fluvial origin in the upper parts of the aquifers and by coarse sands and gravels of fluvioglacial origin in the deeper parts. The upper part locally contains fine sand with dispersed organic matter. The aquifers in contact with the WBV aquifer system on the north and south are between 5 and $20 \mathrm{~m}$ thick and are composed primarily of fine and medium sands. The shallower part of the groundwater system consists of intertill aquifers that are $\sim 5-20 \mathrm{~m}$ thick and primarily composed of fine sands occurring within glacial tills. These aquifers have fluvial and fluvioglacial origin (buried sandur deposits and buried valleys). The confining layers bounding these aquifers are composed of glacial tills of variable thickness (Fig. 2).

The general groundwater flow lines follow the main morphologic features (Fig. 1). The main recharge area is located in the area of the highest elevations (LwowekRakoniewice Rampart). The main discharge areas are located in the valleys surrounding the study area: the Warta
Valley on the east and north, the Obra Valley on the west and the glacial margin Warszawa-Berlin Valley on the south. The greatest downward groundwater gradient is located in the central part of the study area. The difference between the piezometric levels of the deepest and shallowest aquifers is more than $14.0 \mathrm{~m}$ locally (Chmielinko well-Fig. 2a). The greatest upward gradient is located in the discharge areas. The difference between the groundwater levels of the deepest and shallowest aquifers in the Obra River Valley is $8 \mathrm{~m}$.

The WBV aquifer system were designated Major Groundwater Basins (MGB) no. 144 and 145 (Kleczkowski ed. 1990). The Miedzychod-Sierakow aquifer and Warszawa-Berlin glacial marginal valley aquifer were designated Major Groundwater Basins no. 147 and 150, respectively (Fig. 1).

The groundwater system in the eastern part of the study area (Warta Valley region) was studied by Gorski (1989), who described the natural hydrochemical background characteristic of the Quaternary aquifers. The groundwater chemistry of the WBV aquifer (MGB 144) was studied by Dragon (2006), who used multivariate statistics to separate the anthropogenic and geogenic processes influencing the groundwater chemistry. The hydrochemical zonation of the WBV aquifer was described by Dragon and Gorski (2009). In addition, a contaminant impact on the groundwater that is still present at small (initial) levels was discovered (Dragon 2008). Further work performed after one decade documented that the impacted groundwater is still present 
and has led to steady groundwater quality deterioration over time (Dragon 2012). The hydrogeochemical processes occurring in the recharge zone of the aquifer system under investigation were examined in the context of nitrate migration (Dragon 2013). The movement of nitrate plumes to the deepest parts of the flow system that is initiated or intensified by water extraction were documented.

These previous studies documented that the groundwater chemistry of the WBV aquifer originated largely with the inflowing groundwater from aquifers located north of the WBV aquifer. For this reason, this study was extended to the entire aquifer system (regional recharge area and associated discharge areas).

\section{Materials and methods}

This investigation of the groundwater chemistry was performed using data from groundwater sampling completed in the summer of 2009. A total of 185 productive, continuously pumped wells were monitored. The sampling locations are shown in Figs. 4 and 6. The water samples were poured into 100-ml HDPE polyethylene bottles. Separate samples were taken for nutrient analyses (treated with chloroform) and for iron and manganese analysis (treated with $\mathrm{HNO}_{3}$ ). All of the collected bottles were rinsed three times and filled completely to prevent degassing. The samples were stored at cold temperatures ( 4-6 ${ }^{\circ} \mathrm{C}$ ) in a portable refrigerator and immediately (the same day) transported to the laboratory, located in Poznan, Poland. The water temperature $\left(\mathrm{T}^{\circ} \mathrm{C}\right)$, colour $(\mathrm{mgPt} / \mathrm{L})$, alkalinity ( $\left.\mathrm{mg} \mathrm{HCO}_{3} / \mathrm{l}\right)$, electrical conductivity $(\mathrm{EC} \mu \mathrm{S} / \mathrm{cm})$ and $\mathrm{pH}$ were directly measured using a portable meter in the field. The field sampling was performed in accordance with relevant ISO 5667-11 method standards (ISO 5667-11 1993). The chemical analyses were performed at the Institute of Geology of Adam Mickiewicz University, Poznan, using a Compact IC 881Pro ionic chromatograph. The ionic error balance was calculated as a quality control measure, and the calculated error did not exceed $3 \%$.

The levels of stable isotopes $\left(\delta^{18} \mathrm{O}\right.$ and $\left.\delta^{2} \mathrm{H}\right)$ in seven water samples were determined and expressed in terms of the $\delta \mathrm{V}-\mathrm{SMOW}$ (Standard Mean Ocean Water). These water samples were also analysed for $\mathrm{C}^{14}$ (reported as Percent Modern Carbon-pmc). The tritium content was measured in ten water samples and expressed in TUs (tritium units). The isotope analyses were performed in the laboratory of the University of Science and Technology (Faculty of Physics and Applied Computer Science) in Cracow, Poland. The results of isotope analyses presented by Dragon and Gorski (2009) were also used in the data interpretation.

Fig. 3 Piper diagram

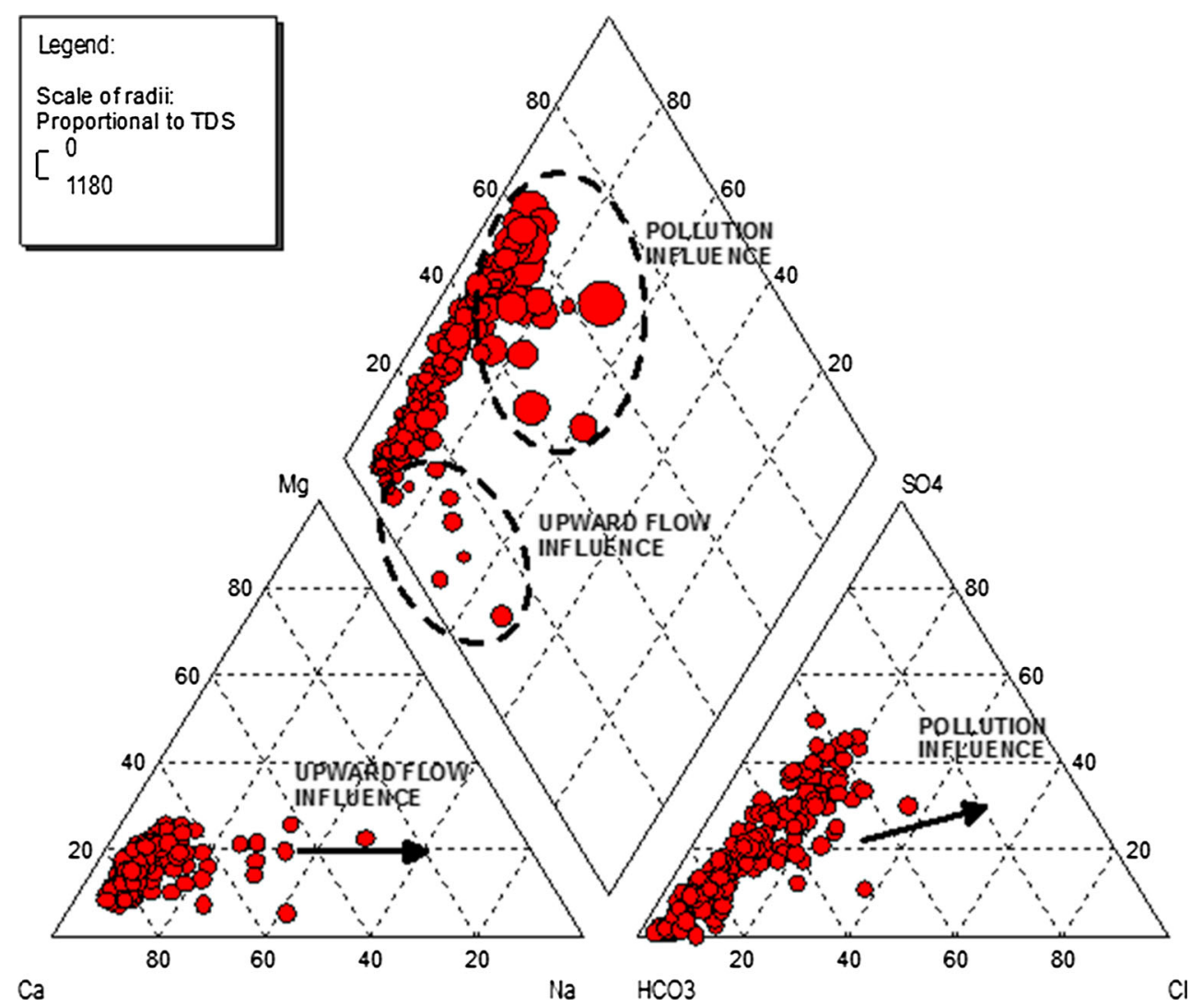


Fig. 4 Generalized map of groundwater chemistry. a 1 alkalinity $\left(\mathrm{HCO}_{3}{ }^{-}\right)>6 \mathrm{meq} / \mathrm{l}$; $2 \mathrm{Fe}^{2+}>4 \mathrm{mg} / \mathrm{l} ; 3 \mathrm{NH}_{4}{ }^{+}$$\mathrm{N}>0.6 \mathrm{mg} / \mathrm{l} ; \mathrm{Na}^{+}>30 \mathrm{mg} / \mathrm{l}$. b $1 \mathrm{Cl}^{-}>60 \mathrm{mg} / \mathrm{l} ; 2$ $\mathrm{SO}_{4}{ }^{2-}>100 \mathrm{mg} / \mathrm{l} ; 3$ total hardness $(\mathrm{TH})>8 \mathrm{meq} / \mathrm{l} ; 4$ TDS $>500 \mathrm{mg} / \mathrm{l}$. a and b 5 location of the sampling sites. Remaining explanations like on Fig. 1. The interpolation was made with use of kriging method
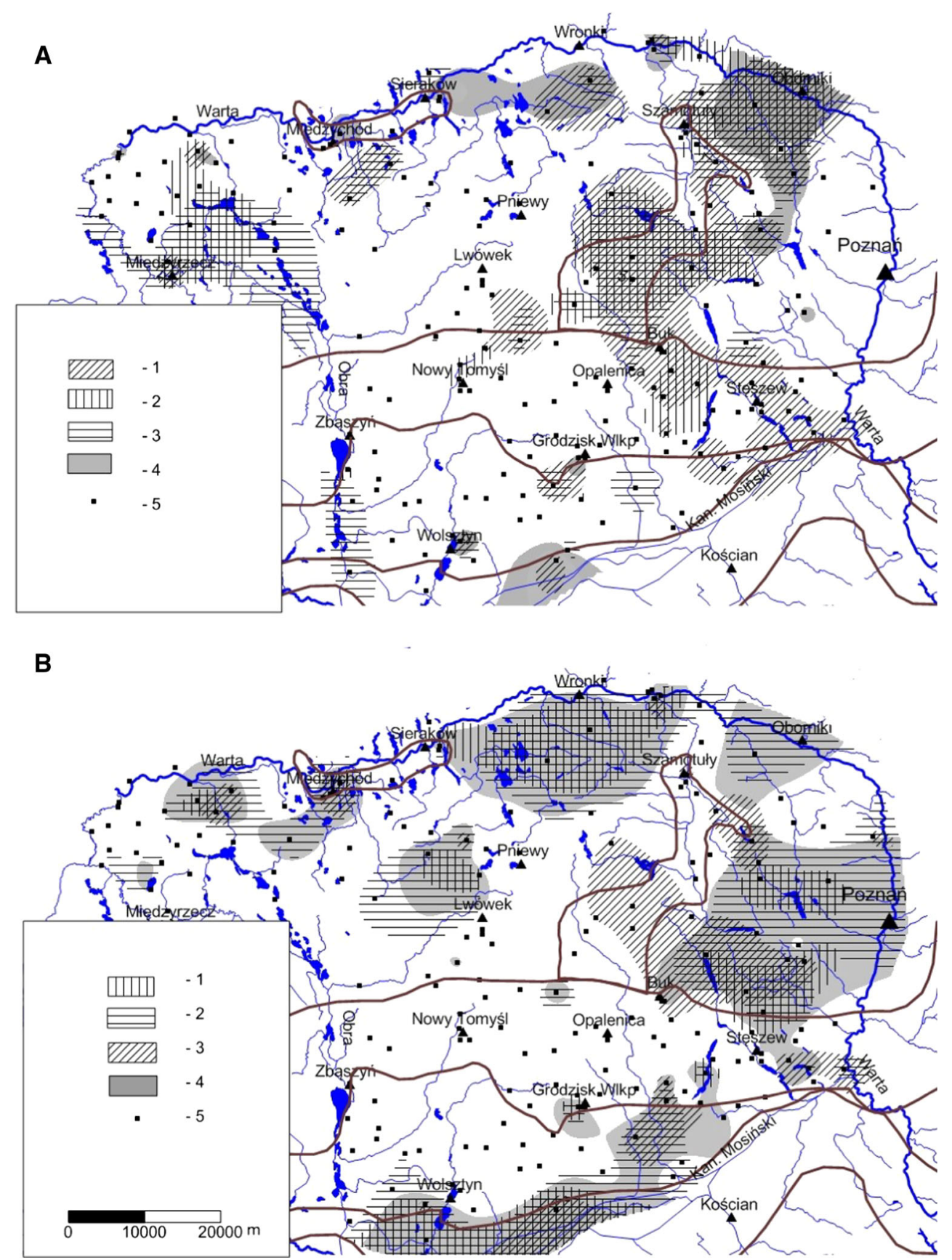

For the characterisation and interpretation of groundwater chemistry, two methods were used: conventional techniques (interpretation of maps, cross sections and diagrams) and multivariate statistics. Factor analysis (FA) was used to generate groups of correlated elements from the initial data set. These groups were included in the principal factor analysis and used to evaluate the processes occurring in the investigated environment. The identification of these factors enabled the genetic interpretation of the environment.
The statistical analysis was performed using the method presented in the previous work of Dragon (2006). The statistical software package Statistica 10 (StatSoft Inc. 2004-2011) was used for the calculations. Prior to the analysis, the initial data set was standardised using criteria presented by Davis (1973). This operation enabled the analysis of parameters of various concentration ranges (macro and micro elements) and parameters that are expressed in different units (aquifer thickness and chemical parameter concentrations). The principal component 


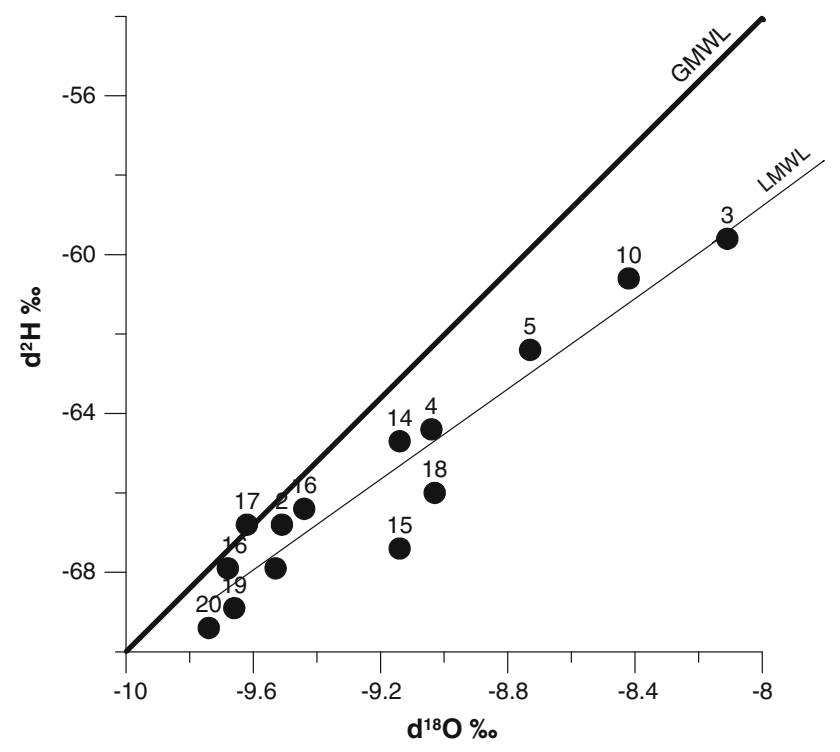

Fig. 5 Isotope composition of groundwater. Numbers identify samples according to Table 2. LMWL: $\mathrm{d}^{2} \mathrm{H}=5.6^{*} \mathrm{~d}^{18} \mathrm{O}-13.8$

extraction technique (Davis 1973; Stat- Soft Inc. 20042011) was the starting point of the FA to generate new groups of variables from the initial data set (the so-called factors). The factor loadings indicate correlations between the factors and the variables (e.g., ion concentration). High factor loadings (near 1 or -1 ) indicate a strong correlation (positive or negative, respectively) between the variable and its associated factor. The factor scores of each sample were calculated. Dalton and Upchurch (1978) found that the factor scores of a sample can be related to the intensity of the associated chemical processes and may then be used to interpret the hydrochemical facies origin. Extremely positive factor scores $(>1)$ indicate the areas that are most affected, and extremely negative scores $(<-1)$ indicate the areas unaffected by the chemical process represented by a factor. Scores near zero indicate areas affected by a process or factor to an average degree. For example, a set of physico-chemical parameters correlated with a particular factor can be explained by a chemical process (anthropogenic or geogenic), which can lead to the variability observed in the data set.

One disadvantage of FA, however, is the difficulty of distinguishing the processes that cause similar variations in the groundwater chemistry (Olmez et al. 1994). In addition, a priori knowledge of the hydrogeologic processes affecting the environment under investigation is required for an effective application of FA (Lawrence and Upchurch 1983).

\section{Results and discussion}

The Piper diagram (Fig. 3; Table 1) shows that the groundwater chemistry generally exhibits relatively little variation. The plotted points of the samples in the diagram indicate the fresh character of the water (Appello and Postma 1994). Most of the samples are classified as $\mathrm{Ca}^{2+}$ $\mathrm{HCO}_{3}{ }^{-}$and $\mathrm{Ca}^{2+}-\mathrm{Mg}^{2+}-\mathrm{HCO}_{3}{ }^{-}$water types. The evident linear scatter type of the water sample distribution is evident in the trend of the diamond-shaped diagram toward the $\mathrm{Ca}^{2+}-\mathrm{HCO}_{3}{ }^{-}-\mathrm{SO}_{4}{ }^{2-}$ water type. Moreover, a distinct shift of the water sample point plots is evident in both the cation and anion triangles. In the anion diagram, several of the sample points are shifted toward the $\mathrm{Cl}^{-}$apex. These samples all contain high TDS concentrations. In the cation diagram, in turn, the samples are shifted toward the $\mathrm{Na}^{+}$ apex. These samples contain TDS concentrations typical of the entire data set.
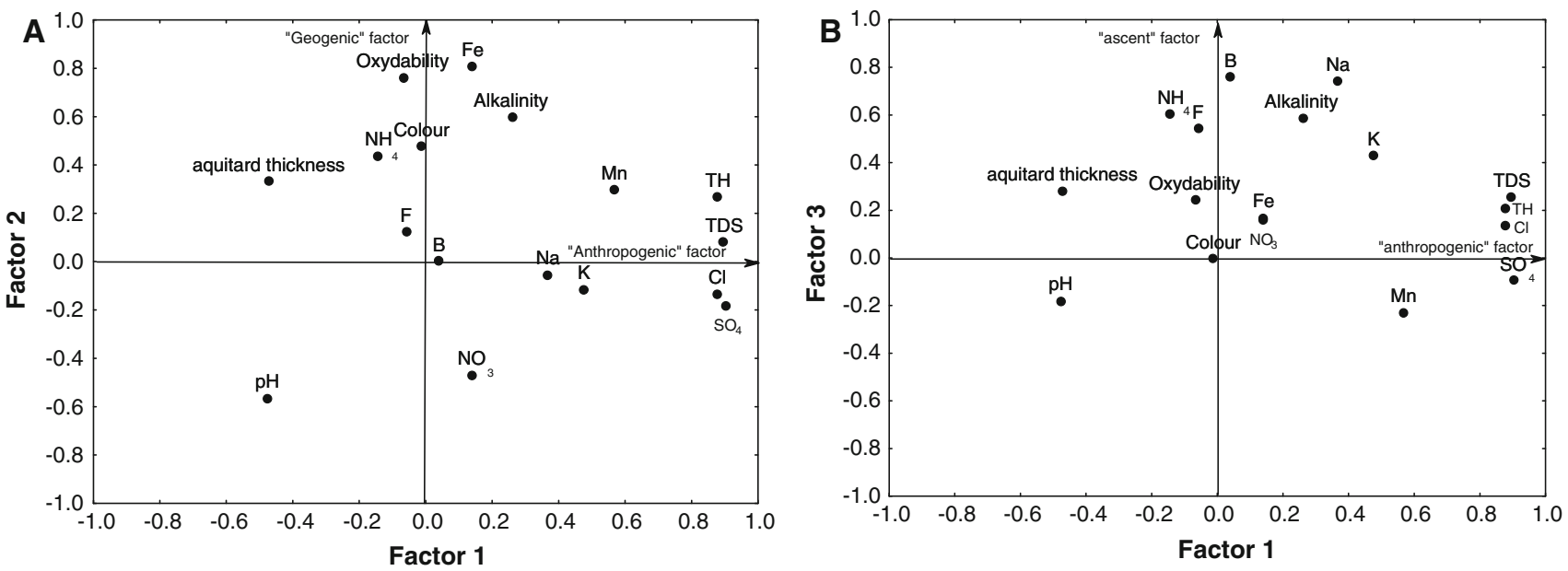

Fig. 6 Plots of factor loadings 
Table 1 Statistical characteristics of the data set

\begin{tabular}{|c|c|c|c|c|c|c|c|}
\hline & Unit & Frequency & Average & Median & Min. & Max. & SD \\
\hline Colour & $\mathrm{mg} \mathrm{Pt} / \mathrm{l}$ & 180 & 14 & 10 & 0 & 120 & 14 \\
\hline $\mathrm{pH}$ & & 184 & 7.45 & 7.42 & 6.88 & 8.29 & 0.22 \\
\hline $\mathrm{HCO}_{3}^{-}$ & meq/l & 185 & 5.1 & 4.9 & 1.7 & 9.2 & 1.5 \\
\hline Total hardness $(\mathrm{TH})$ & & 185 & 6.7 & 6.4 & 1.9 & 16.5 & 2.4 \\
\hline TDS & $\mathrm{mg} / \mathrm{l}$ & 185 & 433 & 402 & 130 & 1,180 & 179 \\
\hline Electrical conductivity (EC) & $\mu \mathrm{S} / \mathrm{cm}$ & 185 & 652 & 618 & 210 & 1,606 & 233 \\
\hline $\mathrm{Cl}^{-}$ & $\mathrm{mg} / \mathrm{l}$ & 185 & 34.2 & 24.6 & 6.9 & 236.5 & 31.1 \\
\hline $\mathrm{SO}_{4}^{2-}$ & & 185 & 76.7 & 56.2 & 3.3 & 317.6 & 68.8 \\
\hline $\mathrm{Ca}^{2+}$ & & 185 & 109.1 & 103.6 & 34.0 & 248.0 & 37.2 \\
\hline $\mathrm{Mg}^{2+}$ & & 185 & 16.1 & 15.6 & 2.6 & 50.6 & 7.7 \\
\hline $\mathrm{Na}^{+}$ & & 185 & 17.5 & 13.0 & 4.6 & 120.6 & 16.7 \\
\hline $\mathrm{K}^{+}$ & & 185 & 4.0 & 3.1 & 0.7 & 70.3 & 7.3 \\
\hline $\mathrm{Fe}^{2+}$ & & 161 & 2.7 & 2.5 & 0.0 & 9.8 & 1.7 \\
\hline $\mathrm{Mn}^{2+}$ & & 176 & 0.2 & 0.2 & 0.0 & 2.1 & 0.2 \\
\hline B & & 166 & 0.038 & 0.021 & 0.005 & 0.347 & 0.055 \\
\hline $\mathrm{F}^{-}$ & & 185 & 0.35 & 0.34 & 0.13 & 0.76 & 0.10 \\
\hline $\mathrm{NO}_{3}{ }^{-}-\mathrm{N}$ & & 185 & 1.47 & 0.01 & 0.005 & 57.80 & 5.32 \\
\hline $\mathrm{NO}_{2}{ }^{-}-\mathrm{N}$ & & 185 & 0.031 & 0.005 & 0.005 & 1.199 & 0.124 \\
\hline $\mathrm{NH}_{4}{ }^{+}-\mathrm{N}$ & & 185 & 0.45 & 0.33 & 0.00 & 5.93 & 0.64 \\
\hline Oxygen consumption & $\mathrm{mg} \mathrm{O}_{2} / 1$ & 174 & 2.1 & 1.8 & 0.5 & 8.3 & 1.3 \\
\hline
\end{tabular}

The spatial distribution of the primary water components are presented on the maps (Fig. 4). To create these maps, interpolation was performed using the kriging method. Then, the areas with a high concentration of each water component were delineated. The zones where the $\mathrm{Cl}^{-}$concentrations exceed $60 \mathrm{mg} / \mathrm{l}$ and the $\mathrm{SO}_{4}{ }^{2-}$ concentrations exceed $100 \mathrm{mg} / \mathrm{l}$ are shown on the maps. In these zones, the total hardness (TH) is typically high (TH $>6 \mathrm{meq} / \mathrm{l}$ ), and the TDS level typically exceeds $500 \mathrm{mg} / \mathrm{l}$. There are also zones of high $\mathrm{TH}(\mathrm{TH}>8 \mathrm{meq} / \mathrm{l})$ where the TDS, $\mathrm{Cl}^{-}$and $\mathrm{SO}_{4}{ }^{2-}$ concentrations are low. However, high alkalinity $(\mathrm{Alk} .>6 \mathrm{meq} / \mathrm{l})$, high $\mathrm{Fe}^{2+}\left(\mathrm{Fe}^{2+}>4 \mathrm{mg} / \mathrm{l}\right)$ and high ammonia $\left(\mathrm{NH}_{4}{ }^{+}>0.6 \mathrm{mg} / \mathrm{l}\right)$ was found in these zones. The zone of high alkalinity and ammonia occupies a distinct part of MGB no. 145 and the vicinity. A relatively high concentration of $\mathrm{Na}^{+}$is evident in these zones. This characteristic is primarily associated with the deepest aquifers located primarily in the discharge areas (river valleys). This type of groundwater typically contains high levels of ammonia, high alkalinity and low TDS. These zones are not easily discernible on the maps because they are small zones restricted to the areas around certain wells. A more detailed characterisation of these zones is presented later in the text. There are also zones of high $\mathrm{Na}^{+}$ concentration and high $\mathrm{Cl}^{-}, \mathrm{SO}_{4}{ }^{2-}$ and TDS concentrations (e.g., in the vicinity of Wronki).

The stable isotope analysis indicates that the groundwater originates from modern infiltration (Table 2). The $\delta^{18} \mathrm{O}$ and $\delta^{2} \mathrm{H}$ values are characteristic of the isotopic composition of meteoric water of the Holocene region of Poland (Rozanski et al. 1993). The Local Meteoric Water Line (shifted right to the Global Meteoric Water Line) presented in Fig. 5 indicates evaporation prior to recharge observed earlier in the Polish Lowland (Zuber et al. 2000). The observed ranges of $\delta^{18} \mathrm{O}$ and $\delta^{2} \mathrm{H}$ values are similar to those found in other aquifer systems located in the Wielkopolska region of Poland (Gorski 1989; Dragon and Gorski 2009).

The ${ }^{14}$ C-calculated "age" of the groundwater also indicates its recent origin, which is consistent with the tritium analysis. The youngest ${ }^{14} \mathrm{C}$ calculated "age" of the groundwater was observed in the upper intertill aquifers located in the recharge area (recent water-Table 2). The oldest water is present in the discharge zone of the WBV aquifer (wells no. 16 and 17-Table 2) and in wells screened in the deepest parts of the flow system (wells no. 3,5 and 6-Table 2), located in the regional discharge area (water older than 1,000 years).

A relatively high tritium content was measured in several of the samples, indicating post-1951 recharge of the aquifer. This value is characteristic primarily of the shallowest wells (wells no. 5, 7, 11, 12, 13, 20 and 21Table 2) located in the recharge area (Lwowek-Rakoniewice Rampart). The depths of these wells do not exceed $50 \mathrm{~m}$. In the deepest wells, the tritium content does not exceed 1 TU. A tritium content of 3.6 TU was documented 
Table 2 Results of the isotopes analyses

\begin{tabular}{|c|c|c|c|c|c|c|c|}
\hline Lp. & Location & $\delta^{18} \mathbf{O}(\%)$ & $\delta^{2} \mathbf{H}(\%)$ & Tritium (T.U) & ${ }^{13} \mathrm{C}(\%)$ V-PDB & ${ }^{14} \mathbf{C}(\mathrm{pmc})$ & Groundwater calculated "age" \\
\hline \multicolumn{8}{|c|}{ The isotope analysis obtained in recent work } \\
\hline 1 & Józefowo 1 bis & -9.68 & -67.4 & $3.6 \pm 0.3$ & -11.8 & $51.8 \pm 1.0$ & "recent" groundwater \\
\hline 2 & Zbąszyń & -9.51 & -66.9 & $0.0 \pm 0.3$ & -12.8 & $52.0 \pm 1.0$ & "recent" groundwater \\
\hline 3 & Skwierzyna 7 & -8.11 & -59.3 & - & -13.0 & $42.6 \pm 1.0$ & 1,600 \\
\hline 5 & Skwierzyna 1 & -8.73 & -62.8 & $2.7 \pm 0.3$ & -12.8 & $45.2 \pm 1.0$ & 1,000 \\
\hline 4 & Ławica & -9.04 & -64.5 & - & -12.3 & $55.4 \pm 1.0$ & "recent" groundwater \\
\hline 6 & Karpicko & -9.53 & -67.8 & - & -13.8 & $28.2 \pm 1.0$ & 5,500 \\
\hline 7 & Grodzisk Wlkp. (Basen) & - & - & $10.0 \pm 0.6$ & - & - & - \\
\hline 8 & Grodzisk Wlkp. AKSUW & - & - & $0.6 \pm 0.3$ & - & - & - \\
\hline 9 & Grodzisk Wlkp. (Chopina) & - & - & $0.2 \pm 0.3$ & - & - & - \\
\hline 10 & Kunowo & -8.42 & -60.6 & $0.1 \pm 0.4$ & -12.9 & $60.0 \pm 1.0$ & "recent" groundwater \\
\hline 11 & Bolewice & - & - & $5.1 \pm 0.4$ & - & - & - \\
\hline 12 & Grońsko & - & - & $4.4 \pm 0.4$ & - & - & - \\
\hline 13 & Pniewy & - & - & $4.0 \pm 0.4$ & - & - & - \\
\hline \multicolumn{8}{|c|}{ The isotope analysis obtained in previous work (Dragon and Gorski. 2009) } \\
\hline 14 & Wąsowo & -9.14 & -64.7 & $0.4 \pm 0.5$ & -13.8 & $62.4 \pm 1.0$ & "recent" groundwater \\
\hline 15 & Porażyn & -9.14 & -67.4 & $0.0 \pm 0.5$ & -13.1 & $55.2 \pm 1.0$ & "recent" groundwater \\
\hline 16 & Jastrzębsko Stare & -9.44 & -66.4 & $0.2 \pm 0.5$ & -13.6 & $53.1 \pm 1.0$ & 200 \\
\hline 17 & Prądówka & -9.62 & -66.8 & - & -11.8 & $46.4 \pm 1.0$ & 150 \\
\hline 18 & Grodzisk Wlkp (Chopina) & -9.03 & -66.0 & $0.4 \pm 0.6$ & - & - & - \\
\hline 19 & Grodzisk Wlkp (AKSUW) & -9.66 & -68.9 & $1.0 \pm 0.6$ & - & - & - \\
\hline 20 & Porażyn (PKP) & -9.74 & -69.4 & $5.0 \pm 0.8$ & -12.5 & $64.7 \pm 1.0$ & "recent" groundwater \\
\hline 21 & Słocin & -9.63 & -67.6 & $15.2 \pm 0.9$ & - & - & "recent" groundwater \\
\hline
\end{tabular}

in only one deep well (more than $80 \mathrm{~m}$ deep; well no. 1 Table 2). This well is located in the central part of the recharge area, in an area of unconfined aquifer conditions. The factor responsible for the deep circulation of young groundwater in this area is groundwater extraction (Dragon 2013).

For more quantitative data interpretation, statistical methods were used. The results of the factor analysis are presented in Table 3 and Fig. 6. The three factors that explain $59.2 \%$ of the total variance were extracted using the principal components extraction technique and then rotated using the varimax method. The factor (with extremely positive factor loadings) that explains $29.5 \%$ of the variance involves the high loadings of $\mathrm{Cl}^{-}, \mathrm{SO}_{4}{ }^{2-}, \mathrm{TH}$, TDS and $\mathrm{Mn}^{2+}$ to some extent; there is a corresponding low factor loading associated with the aquitard thickness and $\mathrm{pH}$. The composition of this factor suggests an anthropogenic origin of these parameters. The concentrations of these parameters usually increase during wells exploitation (Dragon 2012). Moreover, their low concentrations are characteristic of uncontaminated confined aquifers in the Wielkopolska region (Gorski 1989). The low factor loading associated with the aquitard thickness demonstrates that the shallow aquifers are those most vulnerable to contamination. The low factor loading associated with the $\mathrm{pH}$ indicates that water contamination caused the decrease in the $\mathrm{pH}$. This factor is associated with the influence of human activity on the groundwater chemistry, and this factor is therefore classified as anthropogenic.

The oxygen consumption, $\mathrm{Fe}$ and alkalinity are clustered in the second factor. Moreover, a highly negative factor loading associated with the $\mathrm{pH}$ is evident. The water colour and $\mathrm{NH}_{4}{ }^{+}$are also correlated with this factor. These parameters reflect natural (geogenic) hydrogeochemical processes. The behaviour of the parameters grouped together in this factor is primarily associated with the decay of organic matter under anaerobic conditions and an increase in the intensity of dissolution processes. Therefore, this factor is classified as geogenic.

The third factor is associated primarily with the concentrations of $\mathrm{B}, \mathrm{Na}^{+}, \mathrm{NH}_{4}^{+}$and $\mathrm{F}^{-}$and the alkalinity. These parameters reflect the influence of deep water circulation (and relatively long residence time) on the groundwater chemistry. However, the origin of this factor is more difficult to explain than are the others, primarily due to its local occurrence. This factor is typically present in proximity to individual wells only in the areas where the deepest aquifers are present. 
Table 3 The results of the factor analysis (after varimax rotation)

\begin{tabular}{|c|c|c|c|}
\hline parameter & $\begin{array}{l}\text { Factor } 1 \\
\text { "anthropogenic" }\end{array}$ & $\begin{array}{l}\text { Factor } 2 \\
\text { "geogenic" }\end{array}$ & $\begin{array}{l}\text { Factor } 3 \\
\text { "upward } \\
\text { flow" }\end{array}$ \\
\hline Colour & -0.01 & 0.48 & 0.00 \\
\hline $\mathbf{p H}$ & -0.48 & -0.56 & -0.18 \\
\hline $\mathrm{HCO}_{3}$ & 0.26 & 0.60 & 0.59 \\
\hline $\begin{array}{l}\text { Oxygen } \\
\text { consumption }\end{array}$ & -0.07 & 0.76 & 0.24 \\
\hline $\mathrm{Fe}^{2+}$ & 0.14 & 0.81 & 0.17 \\
\hline $\mathrm{Mn}^{2+}$ & 0.57 & 0.30 & -0.23 \\
\hline $\mathbf{B}$ & 0.04 & 0.00 & 0.76 \\
\hline $\mathbf{F}^{-}$ & -0.06 & 0.12 & 0.54 \\
\hline $\mathrm{Cl}^{-}$ & 0.88 & -0.13 & 0.14 \\
\hline $\mathrm{NO}_{3}{ }^{-}-\mathrm{N}$ & 0.14 & -0.47 & 0.16 \\
\hline $\mathbf{N H}_{4}^{-}-\mathbf{N}^{-}$ & -0.14 & 0.44 & 0.60 \\
\hline $\mathrm{Na}^{+}$ & 0.37 & -0.06 & 0.74 \\
\hline $\mathbf{K}^{+}$ & 0.48 & -0.12 & 0.43 \\
\hline $\mathrm{SO}_{4}^{2-}$ & 0.90 & -0.18 & -0.10 \\
\hline Total hardness (TH) & 0.88 & 0.27 & 0.21 \\
\hline $\begin{array}{l}\text { Total dissolved } \\
\text { solids (TDS) }\end{array}$ & 0.90 & 0.08 & 0.25 \\
\hline $\begin{array}{l}\text { Thickness of the } \\
\text { aquitard }\end{array}$ & -0.47 & 0.33 & 0.28 \\
\hline $\begin{array}{l}\text { Percentage of } \\
\text { variance }(\%)\end{array}$ & 29.5 & 19.6 & 10.1 \\
\hline
\end{tabular}

Factor loadings $>0.7$ are marked by bold font

Note that it is difficult to develop explanations for the origins of factors 2 and 3 , because the same set of parameters (alkalinity, $\mathrm{NH}_{4}^{+}$, and aquifer thickness) is observed in association with both of these factors. This overlap is an example of one of the disadvantages of using FA (Olmez et al. 1994).

The spatial distribution of each factor is shown in Fig. 7. The highest factor scores of the anthropogenic factor represent the most vulnerable parts of the aquifer system. The contamination is most extensive in these areas. This situation is representative of the shallow parts of the flow system (shallow intertill aquifers-Fig. 2). The distribution of the scores of the geogenic factors shows that a distinct part of the study area, represented by factor 2 , is influenced by geogenic processes. This distribution is evident throughout the entire area of MGB no. 145. The distribution of the factor scores in the northern part of the WBV aquifer indicates that the effects of these processes have shifted to the south, following the flow patterns. In this case, a distinct part of the WBV aquifer is influenced by the inflow of water from the area outside the aquifer to the north (Dragon and Gorski 2009). The remainder of the study area, where both factors have low factor scores, constitutes an area of relatively higher potential effects due to infiltration. There, the processes associated with factor 2 are less evident. The higher potential effects of infiltration cause these areas to be vulnerable to contamination from the ground surface. However, the anthropogenic factor is also less evident in these areas. One explanation is the type of land use, which is generally dominated by forests. The highest factor scores of factor 3 (i.e., upward flow of groundwater) are distributed in the areas where the deepest aquifers are present. These aquifers are located in the areas of regional discharge, i.e., those with the lowest ground elevations, located in river valleys.

The changes in the concentrations of the same parameters with depth are presented in Fig. 8, in which the parameters influenced primarily by natural (geogenic) processes were chosen for display. The increase in alkalinity with depth is clearly visible on the plot. The highest values of alkalinity were observed in the deepest wells. Moreover, the $\mathrm{Na}^{+}$and $\mathrm{B}$ concentrations are higher in the deep wells. From the surface to a depth of $50 \mathrm{~m}$, their concentrations are relatively uniform. In the deepest wells, a distinct divergence in the plot is evident. The highest concentration of $\mathrm{Na}^{+}$in the shallowest wells is associated with water contamination, which is also indicated by the first (anthropogenic) factor (Fig. 6). A progressive increase in the fluoride concentration is evident down to a depth of $20 \mathrm{~m}$. Below this depth, its concentration is relatively uniform.

To develop a more detailed interpretation of the groundwater chemistry variations with depth, an FA was performed on the data subsets, subdivided based on the thickness of the aquitard (15 $\mathrm{m}$ intervals). This analysis was performed on four data subsets (Table 4). Two factors were obtained from each data group. The observed patterns in these factors are similar to those resulting from the analysis of the complete data set. However, the influence of the aquifer depth became evident. In the data subset of the smallest aquitard thickness $(<15 \mathrm{~m})$, the contributions of the levels of $\mathrm{Na}^{+}, \mathrm{K}^{+}$and $\mathrm{B}$ to the anthropogenic factor is clearer (than those observed with the analysis of the complete data set), which constitutes the evidence for their anthropogenic origin. The composition of the second (geogenic) factor is very similar to that observed with the analysis of the complete data set. The second data subgroup (aquifer thickness between 16 and $30 \mathrm{~m}$ ) displays a pattern very similar to that resulting from the analysis of the entire data set. In the next data subgroup (aquifer thickness between 31 and $45 \mathrm{~m}$ ), the basic composition of the factors is similar to that of the previous subgroups, although the first factor (the most significant) indicates its geogenic origin, and the second factor indicates its anthropogenic origin. This evidence indicates that contamination from the surface is less evident in this data subset. The most important processes that influence the 
Fig. 7 The distribution of the factor scores of each factors: 1 factor scores of factor 1 ("anthropogenic") $>1 ; 2$ factor scores of factor 2 ("geogenic") $>1 ; 3$ factor scores of factor 3 ("ascent") $>1$

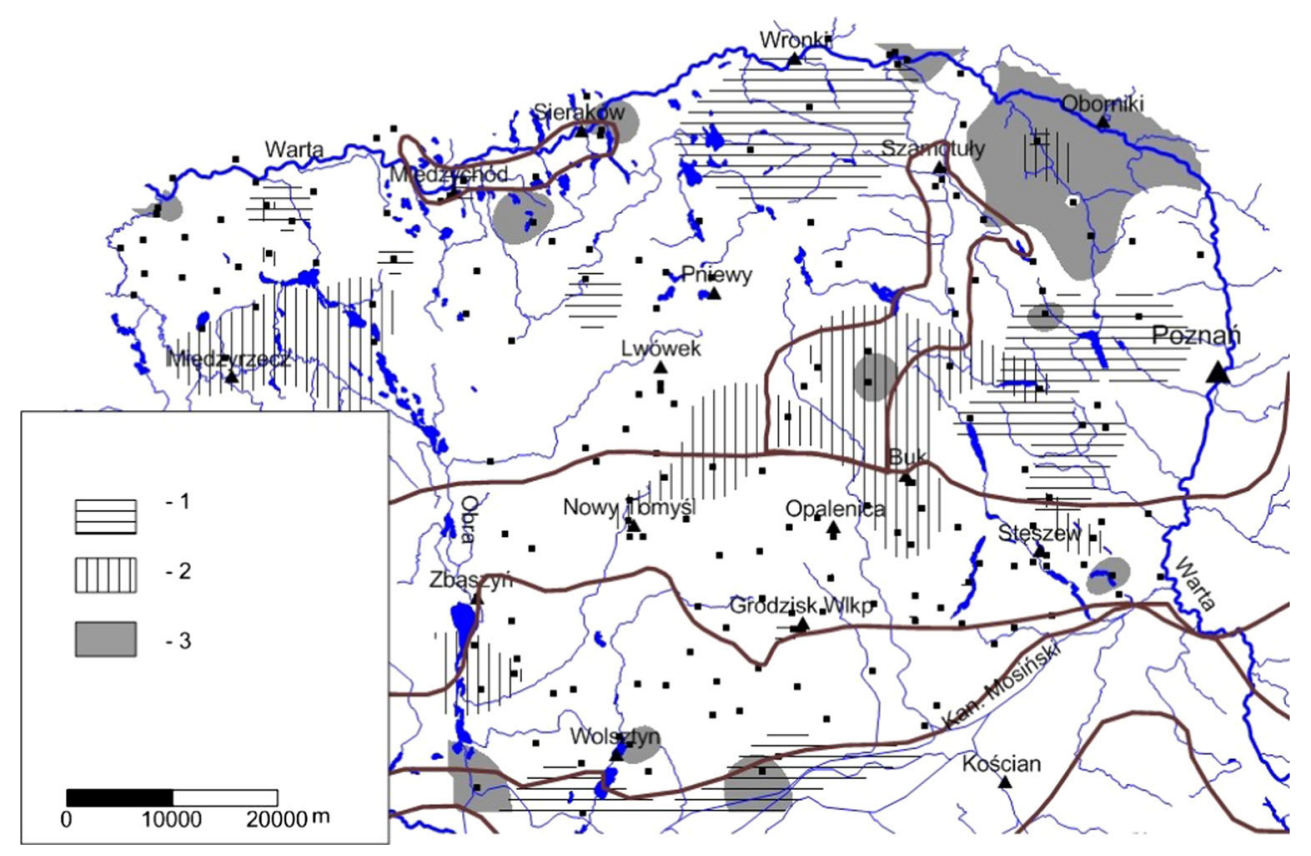

groundwater chemistry have a geogenic origin. The most interesting finding is the composition of the factors of the data subset characterised by an aquitard thickness of more than $46 \mathrm{~m}$. The composition of the first factor (the most significant) is very similar to that of factor 3 (upward flow) extracted from the entire data set. The most distinct contributions by water colour, oxygen consumption and $\mathrm{F}^{-}$are evident in this factor (compared with that of the entire data set). The composition of the second factor is very similar to that of the geogenic factor extracted from the entire data set. These factors indicate that the anthropogenic impact on the groundwater chemistry is negligible in the deepest part of the flow system. The chemistry of the groundwater in the deepest part of the flow system is primarily due to the influence of groundwater from deep circulation and from the influence of natural processes related to the decomposition of organic matter, followed by the increase in the solubility of the geologic elements. The spatial distribution of the factors (Fig. 7) indicates that the first process is related to the deepest aquifers located primarily in the regional discharge zones, which is consistent with the results of the isotope analysis. The oldest calculated age of the groundwater was observed in these aquifers (wells located in Karpicko and Skwierzyna). Thus, the isotope analysis confirms the upward-flow origin of this factor (and factor 3 resulting from analysis of the entire data set). The shift of points in the cation triangle in the Piper diagram (Fig. 3) is caused by this process. The second group of processes (geogenic) is related to the remaining part of the data set that is not influenced by contamination.

The results of the FA indicate that contamination from the ground surface considerably influences the groundwater chemistry. Moreover, in a distinct part of the study area, the geogenic and anthropogenic processes overlap. Consequently, interpreting the natural changes in the groundwater chemistry is difficult. For this reason, the data subset that is influenced by natural geochemical processes (i.e., not affected by human activity) was analysed using the method presented by Dragon (2008). The results of the FA were helpful in distinguishing between uncontaminated and contaminated groundwater. First, the factor scores of each sample were calculated. The subset of the results characterised by factor scores $<0$ for the first anthropogenic factor was marked. Then, the results of water samples that contained nitrate were removed. After this procedure, a subset of 68 analytical results (36\% of the complete data set) representing the natural groundwater chemistry was obtained. The remaining part of the data set represents the groundwater chemistry that is impacted by anthropogenic contamination.

To develop an interpretation of the variations in the natural groundwater chemistry, the sum of the major anions and sum of the major cations were separately correlated with each anion and each cation, respectively, in scatter diagrams (Fig. 9). For a better understanding of the relationships between anthropogenic and natural geochemical processes, both groups of data are presented: those data associated with natural geochemical processes and the remaining data (associated with contamination). A welldefined relationship is evident in the $\mathrm{HCO}_{3}{ }^{-}, \mathrm{Ca}^{2+}$ and $\mathrm{Mg}^{2+}$ plots of both data subsets presented in the diagrams. The highest concentrations of $\mathrm{Ca}^{2+}$ and $\mathrm{Mg}^{2+}$ in the contaminated water are evident, indicating the contribution of these parameter concentrations to the groundwater 

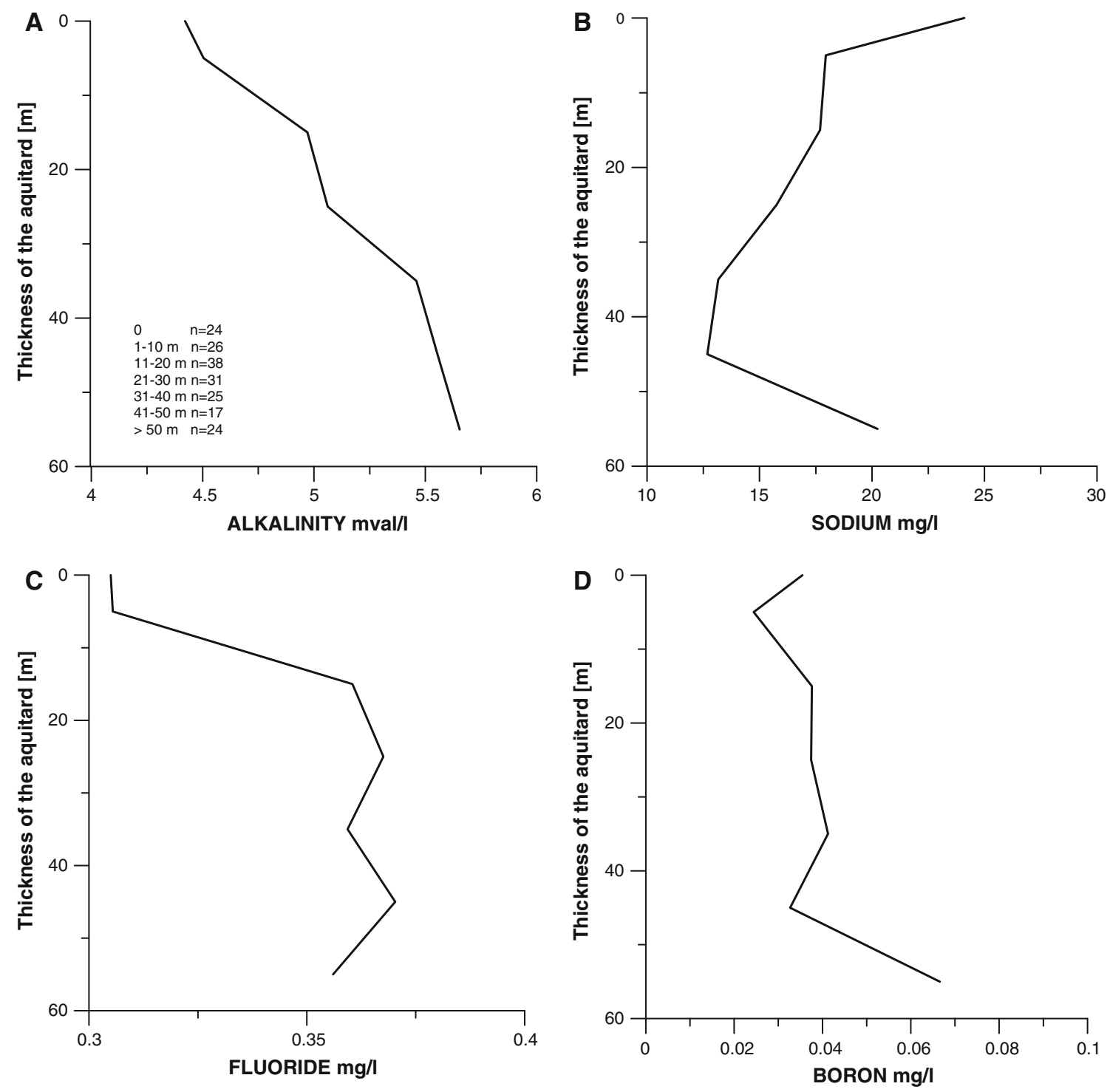

Fig. 8 The variability of choosing parameters concentration with depth $(n=185)$

mineralisation. This contribution' is reflected in the FA results by the contribution of $\mathrm{TH}$ to the first anthropogenic factor (Table 3). In the natural groundwater, the lack of a correlation is evident in the $\mathrm{Cl}^{-}, \mathrm{SO}_{4}{ }^{2+}$ and $\mathrm{Na}$ diagrams, whereas in the contaminated water, this relationship is evident, which shows the impact of contamination on the levels of these parameters. The increase in the level of TDS in the contaminated groundwater evident in the Piper diagram (Fig. 3) is due to this process. The distinct shift of certain points in the $\mathrm{Na}^{+}$diagram (in a direction toward higher concentrations) and $\mathrm{Ca}^{2+}$ diagram (toward lower concentrations) is apparent. These points represent the deepest wells located in the discharge zones (Karpicko, Skwierzyna, Zielonagora and Zielatkowo). The process responsible for this relationship is the cation exchange that occurs in the deepest parts of the flow system. All of these samples contain the highest concentrations of $\mathrm{F}^{-}$and $\mathrm{B}$, confirming the oldest age of this groundwater. The locations of these wells in the regional discharge area, where a high upward gradient is present (Fig. 2), indicate that this relationship is caused by the upward flow of water originating from deep water circulation.

The spatial distribution of $\mathrm{F}^{-}$is shown in Fig. 10. The lowest concentrations $(<0.2 \mathrm{mg} / \mathrm{l})$ are present in the recharge area (Lwowek-Rakoniewice Rampart). From there, an increase in the fluoride concentrations in all directions is evident. Thus, the fluoride concentrations clearly follow the flow pattern of the groundwater, and the increases in its concentration coincide with the flow paths. Saxena and Ahmed (2001) concluded that the presence of $\mathrm{F}^{-}$in groundwater is related to the residence time of the groundwater in the geologic environment. The increase in 
Table 4 The results of the factor analysis (after varimax rotation) performed for the data subsets allocated according to different aquitard thickness

\begin{tabular}{|c|c|c|c|c|c|c|c|c|}
\hline \multirow[t]{2}{*}{ Parameter } & \multicolumn{2}{|c|}{$\begin{array}{l}\text { Aqitard thickness }<15 \mathrm{~m} \\
(n=71)\end{array}$} & \multicolumn{2}{|c|}{$\begin{array}{l}\text { Aqitard thickness } \\
16-30 \mathrm{~m}(n=47)\end{array}$} & \multicolumn{2}{|c|}{$\begin{array}{l}\text { Aqitard thickness } \\
31-45 \mathrm{~m}(n=39)\end{array}$} & \multicolumn{2}{|c|}{$\begin{array}{l}\text { Aqitard thickness }>46 \mathrm{~m} \\
(n=26)\end{array}$} \\
\hline & Factor 1 & Factor 2 & Factor 1 & Factor 2 & Factor 1 & Factor 2 & Factor 1 & Factor 2 \\
\hline Colour & 0.13 & 0.71 & -0.22 & 0.50 & 0.17 & 0.05 & 0.77 & 0.23 \\
\hline pH & -0.62 & -0.40 & -0.61 & -0.10 & $-\mathbf{0 . 7 0}$ & -0.27 & 0.02 & $-\mathbf{0 . 8 0}$ \\
\hline $\mathrm{HCO}_{3}^{-}$ & 0.64 & 0.48 & 0.57 & 0.65 & 0.93 & 0.22 & 0.56 & 0.74 \\
\hline Oxygen consumption & 0.13 & 0.78 & -0.06 & 0.82 & 0.77 & -0.21 & 0.70 & 0.50 \\
\hline $\mathrm{Fe}^{2+}$ & -0.09 & 0.82 & 0.42 & 0.54 & 0.73 & -0.24 & -0.17 & 0.67 \\
\hline $\mathrm{Mn}^{2+}$ & 0.45 & 0.18 & 0.55 & 0.18 & -0.16 & 0.39 & -0.02 & -0.19 \\
\hline B & 0.73 & 0.15 & 0.25 & 0.49 & 0.34 & 0.17 & 0.92 & 0.11 \\
\hline $\mathbf{F}^{-}$ & -0.08 & 0.35 & 0.04 & 0.41 & 0.48 & -0.09 & 0.79 & -0.06 \\
\hline $\mathrm{Cl}^{-}$ & 0.94 & -0.09 & 0.90 & -0.12 & 0.10 & 0.89 & 0.23 & 0.40 \\
\hline $\mathrm{NO}_{3}^{-}-\mathrm{N}$ & 0.47 & -0.37 & -0.03 & -0.04 & 0.06 & 0.48 & -0.25 & 0.14 \\
\hline $\mathrm{NH}_{4}^{+}-\mathrm{N}$ & 0.11 & 0.66 & 0.06 & 0.82 & 0.77 & -0.26 & 0.69 & 0.44 \\
\hline $\mathrm{Na}^{+}$ & 0.82 & 0.01 & 0.58 & 0.54 & 0.75 & 0.22 & 0.95 & 0.16 \\
\hline $\mathbf{K}^{+}$ & 0.74 & -0.01 & 0.67 & 0.32 & 0.72 & 0.46 & 0.68 & 0.57 \\
\hline $\mathrm{SO}_{4}^{2-}$ & 0.78 & -0.19 & 0.91 & -0.13 & -0.05 & 0.86 & -0.52 & 0.18 \\
\hline Total hardness (TH) & 0.85 & 0.08 & 0.96 & 0.12 & 0.70 & 0.65 & -0.19 & 0.90 \\
\hline Total dissolved solids (TDS) & 0.91 & -0.02 & 0.95 & 0.12 & 0.53 & 0.79 & 0.37 & 0.75 \\
\hline Percentage of variance $(\%)$ & 36.6 & 16.9 & 38.4 & 16.36 & 37.4 & 18.0 & 41.2 & 17.8 \\
\hline
\end{tabular}

Factor loadings $>0.7$ are marked by bold font

the $\mathrm{F}^{-}$concentration along the flow path in the present study is related to the relatively longer residence time of the groundwater in the aquifer system. Thus, the distribution of the $\mathrm{F}^{-}$concentrations can be helpful for identifying the zones where extensive infiltration occurs (recharge areas).

\section{Conclusions}

Based on the statistical analysis and the standard interpretation (analyses of the maps, cross sections and diagrams), the hydrochemical zonations of a regional aquifer system were delineated. Factor analysis was used to identify three primary groups of processes. The most important factors that control the groundwater chemistry are anthropogenic impacts that cause the contamination of groundwater, geogenic processes that increase the dissolution of geological environmental components and the effects of deep water circulation on the groundwater chemistry.

The analysis of the concentrations of the groundwater components with depth revealed certain variations in the $\mathrm{Na}^{+}$and $\mathrm{B}$ concentrations. The highest concentrations were observed in the deepest parts of the flow system. The concentrations of these parameters are also higher in the shallowest wells. The factor analysis of the data subgroups was used to divide the data on the basis of the aquitard thickness and identify the origin of this differentiation. The sharp increases in the concentrations in the deepest part of the flow system are associated with the effect of the upward inflow of groundwater from the deepest part of the aquifer system. This finding is consistent with the isotope analysis, as the oldest water is one characteristic of this groundwater. The high concentrations of $\mathrm{Na}^{+}$and $\mathrm{B}$ in the shallow part of the flow system are associated with contamination from the surface.

To develop a more precise interpretation of the natural (geogenic) groundwater chemistry variations, the subgroup of the analytical results not influenced by groundwater contamination was defined. The changes in the groundwater chemistry in the deepest part of the flow system were found to be caused by cation exchange. This process was identified in the deepest wells located in the discharge zones, which led to changes in the water chemistry from one of predominantly $\mathrm{Ca}^{2+}-\mathrm{HCO}_{3}{ }^{-}$chemistry to one of predominantly $\mathrm{Na}^{2+}-\mathrm{HCO}_{3}{ }^{-}$chemistry.

The spatial distribution of $\mathrm{F}^{-}$shows a clear relationship with the flow pattern. The lowest $\mathrm{F}^{-}$concentration was observed in the regional recharge zone, where the highest effective infiltration occurs.

This groundwater chemistry zonation can be helpful in identifying the groundwater flow patterns and in determining the vulnerability of groundwater to contamination. The zones where the geogenic processes are less effective 

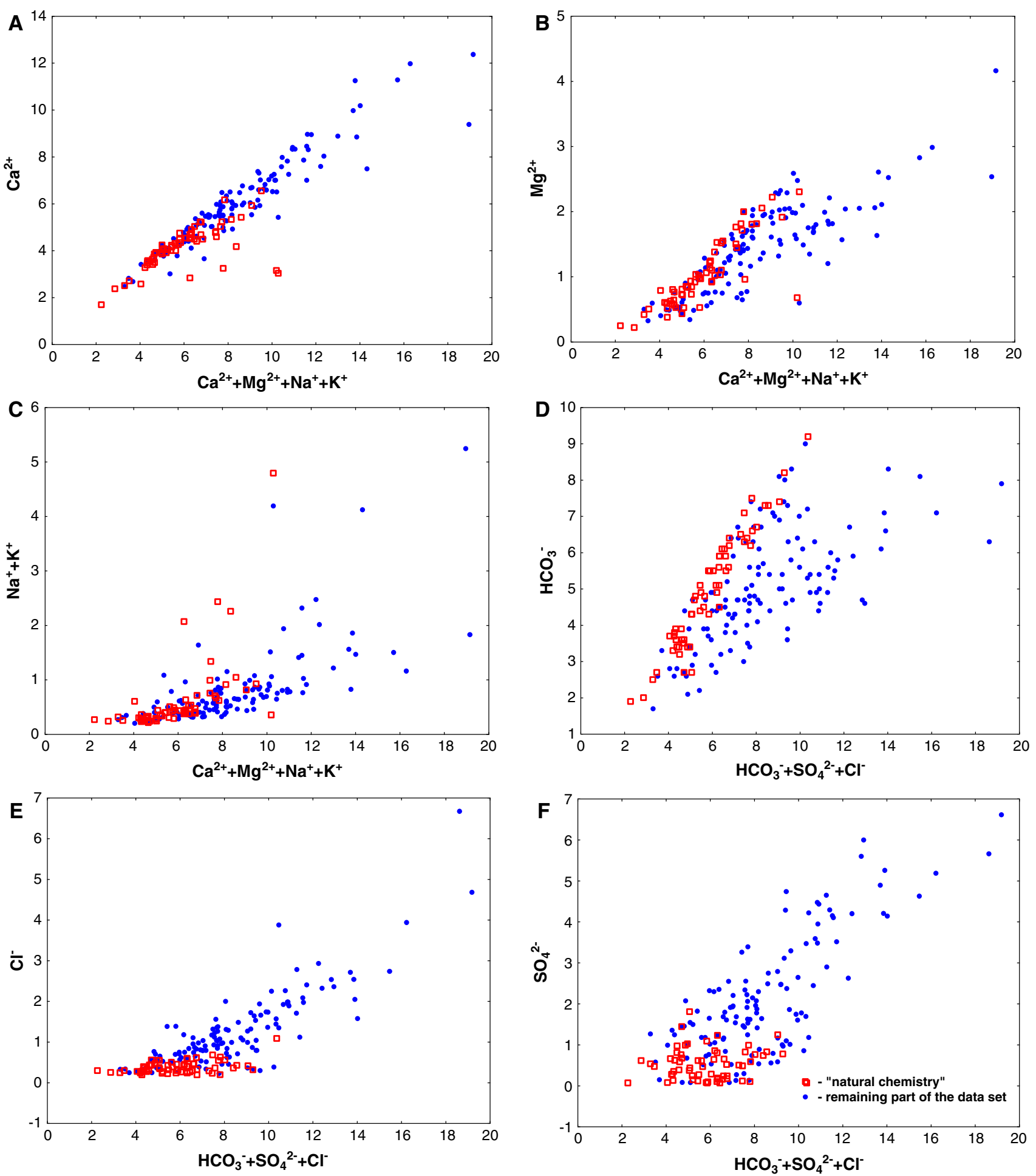

Fig. 9 Plot of sum anions versus each anion and sum of cations versus each cation (concentrations in meq/l)

(identified by the lowest factor scores of the geogenic factor) represent the parts of the flow system where the highest effective infiltration occurs. At this time, these zones are the most vulnerable to contamination from the surface. In contrast, the zones where upward flow of groundwater influences was identified are those least vulnerable to groundwater contamination.

The present study demonstrates the general usefulness of groundwater chemistry differentiation in support of identification of groundwater flow patterns. It also 
Fig. 10 The distribution of fluoride in the part of the data set that is characterized by "natural" groundwater chemistry. By black points the sampling sites from the "natural" data subset is marked

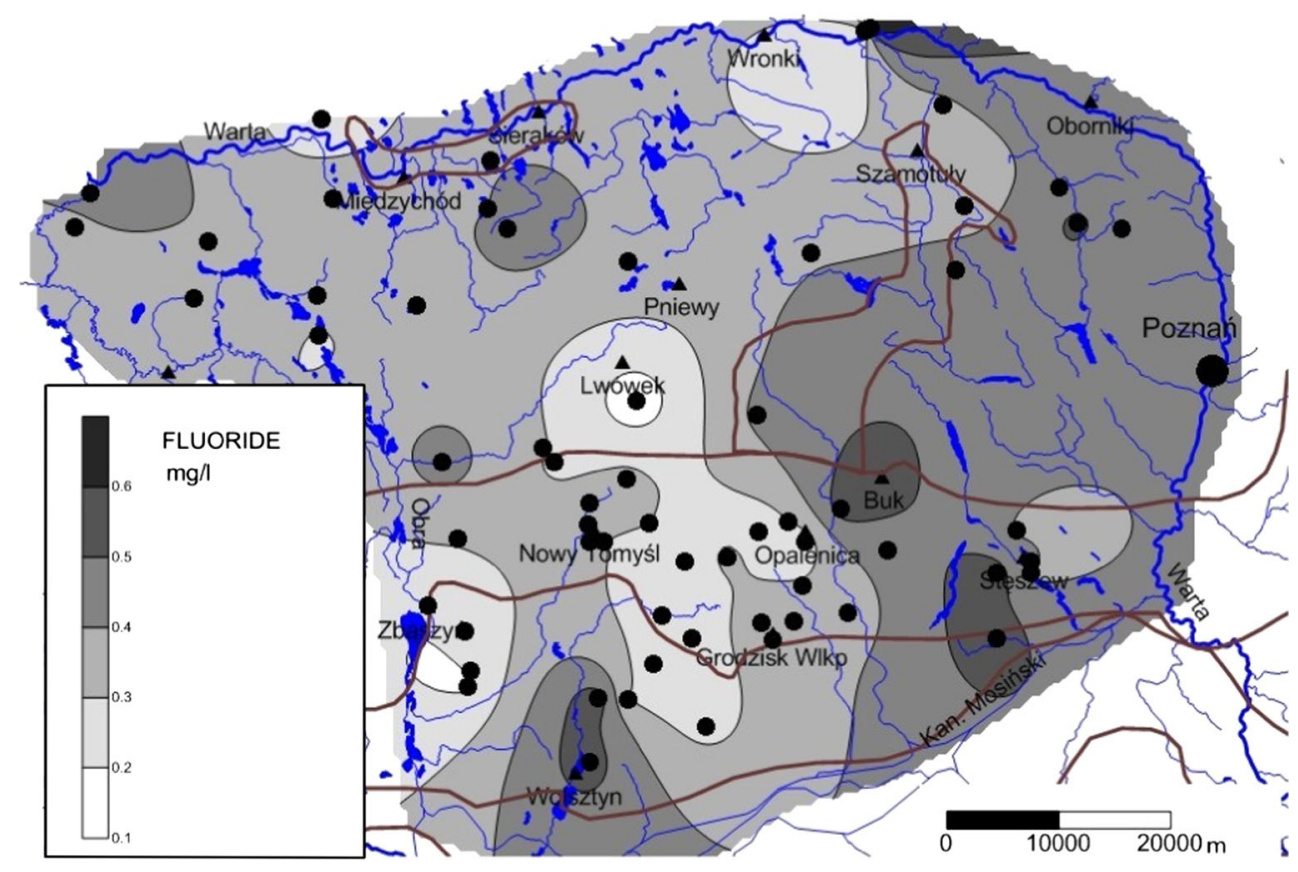

demonstrates the importance of using chemical data to verify the connectivity between different aquifers. These interpretations may be useful for better management of water resources on a regional scale.

Acknowledgments This work was made possible by the financial support of the Ministry of Science and Higher Education (Grant no 2164/B/T02/2007/33).

Open Access This article is distributed under the terms of the Creative Commons Attribution License which permits any use, distribution, and reproduction in any medium, provided the original author(s) and the source are credited.

\section{References}

Afsin M (1996) Hydrochemical evolution and water quality along the groundwater flow path in the Sandikli plain, Afyon. Turk Env Geol 31(3/4):221-230

Al-Mashaikhi K, Oswald S, Attinger S, Buchel G, Knoller K, Strauch G (2012) Evaluation of groundwater dynamics and quality in the Najd aquifers located in the Sultanate of Oman. Env Earth Sci 66:1195-1211

Appello CAJ, Postma D (1994) Geochemistry, groundwater and pollution. A. A Balkema, Rotterdam

Back W (1966) Hydrogeochemical facies and groundwater flow pattern in the northern part of the Atlantic Coastal Plain. U.S. Geological Survey Professional Paper 498-A

Carillo-Rivera JJ, Cardona A, Moss D (1996) Importance of the vertical component of groundwater flow: a hydrochemical approach in the valley of San Luis Potosi, Mexico. J Hydrol 185:23-44

Coetsiers M, Walraevens K (2006) Chemical characterization of the Neogene Aquifer, Belgium. Hydrogeol J 14:1556-1568

Dalton MG, Upchurch SB (1978) Interpretation of hydrochemical facies by factor analysis. Ground Water 16(4):228-233
Davis JC (1973) Statistics and data analysis in Geology. Wiley, New York

Dragon K (2006) Application of factor analysis to study contamination of a semi-confined aquifer (Wielkopolska Buried Valley aquifer, Poland). J Hydrol 331(1-2):272-279

Dragon K (2008) The influence of anthropogenic contamination on the groundwater chemistry of a semi-confined aquifer (the Wielkopolska Buried Valley Aquifer, Poland). Water Resour Manag 22(3):343-355

Dragon K (2012) The changes of groundwater chemistry of semiconfined buried valley aquifer during one decade of water exploitation. Env Earth Sci 65(4):1283-1290

Dragon K (2013) Groundwater nitrate pollution in the recharge zone of a regional Quaternary flow system (Wielkopolska region, Poland). Env Earth Sci 68(7):2099-2109

Dragon K, Gorski J (2009) Identification of hydrogeochemical zones in postglacial buried valley aquifer (Wielkopolska Buried Valley aquifer, Poland). Env Geol 58(4):859-866

Drever JI (1997) The geochemistry of natural waters. Surface and groundwater environments. Prentice Hall, Upper Saddle River 07458

Gorski J (1989) Główne problemy chemizmu wód podziemnych utworów kenozoiku środkowej Wielkopolski (The Main Hydrochemical Problems of Cainozoic Aquifers Located in Central Wielkopolska) Zeszyty Nauk. AGH:45 Kraków Poland

Hendry MJ, Schwartz FW (1990) The chemical evolution of groundwater in the Milk River Aquifer Canada. Ground Water 28(2):253-261

ISO 5667-11 (1993) Water quality-sampling-part 11: guidance on sampling of groundwaters. International Organization for Standardization, Geneva, Switzerland

Jackson D, Lloyd JW (1984) An integrated hydrochemical approach to deduce the response of an aquifer system during its history of abstraction. Ground Water 22(6):735-745

Jeong CH (2001) Effect of land use and urbanization on hydrochemistry and contamination of groundwater from Taejon area, Korea. J Hydrol 253:194-210

Kleczkowski AS (eds) (1990) Mapa obszarów Głównych Zbiorników Wód Podziemnych (GZWP) w Polsce wymagających 
szczególnej ochrony, The map of the critical protection areas of the major groundwater basins (MGWB) in Poland, Institute of Hydrogeology and Engineering Geology. Academy of Mining and Metallurgy, Cracow

Lawrence AR, Upchurch SB (1983) Identification of recharge areas using geochemical factor analysis. Ground Water 20(6):680-687

Moosavirad SM, Janardhana MR, Khairy H (2013) Impact of anthropogenic activities on the chemistry and quality of groundwater: a case study from a terrain near Zarand City, Kerman Province, SE Iran. Env Earth Sci 69:2451-2467

Ochsenkuhn KM, Kontoyannakos J, Ochsenkuhn-Petropulu M (1997) A new approach to a hydrochemical study of groundwater flow. J Hydrol 194:64-75

Olmez I, Beal JW, Villaume JF (1994) A new approach to understanding multiple-source groundwater contamination: factor analysis and chemical mass balances. Water Resour Res 28(5):1095-1101

Ophori DU, Toth J (1989) Patterns of ground-water chemistry, Ross Creek Basin, Alberta, Canada. Ground Water 27(1):20-26

Perea R, Rodriguez- Rodriguez M (2009) Water quality for different uses in the main groundwater bodies of the Guadalquivir River Watershed, Atlantic Basin, Spain. Envoron Earth Sci 59:75-86

Pilla G, Sacchi E, Zuppi G, Braga G, Ciancetti G (2006) Hydrochemistry and isotope geochemistry as tools for groundwater hydrodynamic investigation in multilayer aquifers: a case study from Lomellina, Po plain, South-Western Lombady, Italy. Hydrogeol J 14:795-808

Rozanski K, Araguas-Araguas L, Gonfiantini R (1993) Isotopic patterns in modern global precipitation. Am Geophys Union Geophys Monogr 78:1-36

Saxena VK, Ahmed S (2001) Dissolution of fluorine in groundwater: a water-rock interaction study. Env Geol 40(9):1084-1087

StatSoft, Inc. 2004-2011. STATISTICA (data analysis software system), Version 10. Available from: https://www.statsoft.com. Accessed 2014

Thyne G, Guler C, Poeter E (2004) Sequential analysis of the hydrochemical data for watershed characterization. Ground Water 42(5):711-723

Tweed SO, Weaver TR, Cartwright I (2005) Distinguishing groundwater flow path in different fractured-rock aquifers using groundwater chemistry : Dandenong Ranges, southeast Australia. Hydrogeol J 13:771-786

Zuber A, Weise SM, Osenbruck K, Pajnowska H, Grabczak J (2000) Age and recharge pattern of water in the Oligocen of the Mazovian basin (Poland) as indicated by environmental tracers. J Hydrol 233:174-188 